\title{
Effect of Maternal Pyridoxine Ingestion on Cord Blood 5-Hydroxytryptamine Concentration
}

\author{
JULIAN L. BERMAN \\ From the Bernhard Baron Memorial Research Laboratories and the Institute of Obstetrics \\ and Gynaecology, Queen Charlotte's Maternity Hospital, London
}

Newborn infants have relatively low levels of circulating 5-hydroxytryptamine (5HT, serotonin) when compared with adults or children (Mitchell and Cass, 1959; Hazra, Benson, and Sandler, 1965). Values in cord blood are similarly low (R. S. Stacey, 1965, personal communication). Berman, Justice, and Hsia (1965) have confirmed these findings in low birth weight and full-term newborn infants and have shown in common with Hazra et al. that 5HT concentration rises slowly after birth, to reach the adult level during the first month of life. They further demonstrated that these values could be rapidly increased during the first few days of life by the administration of pyridoxine (vitamin B6).

The present study was undertaken to determine whether a similar rise occurs in the newborn infant, if vitamin B6 is given to the mother during the final three to five weeks of gestation.

\section{Subjects and Methods}

The patients taking part in the study consisted of 59 women selected at random from the antenatal clinic at Queen Charlotte's Maternity Hospital. They were all between 20 and 35 days from term as measured by fundal height and the date of the last menstrual period.

Each was assigned to one of three groups by rotation. Group A was a control group and received no supplementary pyridoxine. Group B received $10 \mathrm{mg}$. pyridoxine per day, and Group $\mathrm{C}$ received $50 \mathrm{mg}$. per day, until delivery.

After delivery it was ascertained by direct questioning that each woman had in fact taken the tablets each day. Two mothers were excluded from the study because of severe pre-eclamptic toxaemia, and 17 mothers and infants were excluded for a variety of technical reasons. Thus $\mathbf{4 0}$ mothers and infants remained in the study.

Venous blood was collected from the cord of each infant and analysed for 5HT according to the method of Contractor (1964). When feasible, a 24-hour urine sample was collected and assayed for 5-hydroxyindoleacetic acid (5HIAA) by the method of Udenfriend, Titus, and Weissbach (1955). Such urine samples were

Received May 6, 1965. obtained during the first 48 hours of life from 28 infants. Maternal blood samples for $5 \mathrm{HT}$ estimation were collected on three different occasions : at initial examination; during the second stage of labour; and 8-10 days after delivery before the patient left hospital. In addition 33 women had platelet counts performed on initial and post-partum blood samples.

\section{Results}

Mean values for cord blood 5HT and urinary 5HIAA are shown in Table I. There was no significant difference between test and control groups.

TABLE I

Cord Blood 5HT and Urinary 5HIAA Levels in Newborn Infants in Controls and in 2 Groups Where Maternal Pyridoxine Supplements Were Given

\begin{tabular}{|c|c|c|}
\hline$\underset{\text { (see text) }}{\text { Group }}$ & $\begin{array}{c}\text { Cord Blood } \\
\text { HT (ng./ml.) }\end{array}$ & $\begin{array}{l}\text { Urine 5HIAA } \\
(\mu \mathrm{g} . / 24 \mathrm{hr} .)^{\star}\end{array}$ \\
\hline $\begin{array}{l}\text { A (control) } \\
\text { B (10 mg. pyridoxine daily) } \ldots \\
\text { C (50 mg. pyridoxine daily) .. }\end{array}$ & $\begin{array}{l}50 \pm 22(13) \\
68 \pm 36(13) \\
47 \pm 26(14)\end{array}$ & $\begin{array}{l}109 \pm 71(9) \\
218 \pm 169(8) \\
132 \pm 83(11)\end{array}$ \\
\hline
\end{tabular}

$\star$ Expressed as mean $\pm \underset{\text { standard deviation. Number of infants in }}{\text { parentheses. }}$

5HT levels in women receiving pyridoxine did not differ significantly from the control group at any of the times tested (Table II). However, within each group, values rose significantly between initial and post-partum samplings. In addition, in groups B and $C$, a significant rise was also found between initial and parturition samples.

Platelet counts tended to rise during the postpartum period in all groups (Table II). However, this rise did not reach significance. There was no correlation between cord blood 5HT and urinary 5HIAA nor any correlation between either of these and maternal 5HT or platelets. Maternal age, birth weight, and Apgar scores were also unrelated to cord blood $5 \mathrm{HT}$. 
TABLE II

Maternal Blood 5HT and Platelet Concentrations During Final 3-5 Weeks of Pregnancy, Parturition, and Post-partum Period in Control and Pyridoxine-supplemented Groups

\begin{tabular}{|c|c|c|c|c|c|}
\hline \multirow{2}{*}{ Group } & \multicolumn{3}{|c|}{ Blood 5HT (ng./ml.)^ } & \multicolumn{2}{|c|}{ Blood Platelets $\times 1,000 /$ c.mm. ${ }^{\star}$} \\
\hline & Initial & Parturition & Post Partum & Initial & Post Partum \\
\hline $\begin{array}{l}\text { A (control) .. } \\
\text { B (10 mg. pyridoxine daily) } \\
\text { C (50 mg. pyridoxine daily) }\end{array}$ & $\begin{array}{l}135 \pm 41 \\
133 \pm 44 \\
116 \pm 69\end{array}$ & $\begin{array}{l}135 \pm 52 \\
154 \pm 66 \neq \\
139 \pm 76 \neq\end{array}$ & $\begin{array}{l}199 \pm 62(13) \dagger \\
214 \pm 74(13) \dagger \\
177 \pm 81(14) \dagger\end{array}$ & $\begin{array}{l}172 \pm 58 \\
174 \pm 53 \\
198 \pm 62\end{array}$ & $\begin{array}{l}197 \pm 62(7) \\
199 \pm 54(12) \\
249 \pm 71(14)\end{array}$ \\
\hline
\end{tabular}

* Expressed as mean \pm one standard deviation. Number of mothers in parentheses. Difference between initial and parturition or postpartum samples. $\quad+\mathrm{p}=<0.001 . \quad \neq \mathrm{p}=<0.05$.

\section{Discussion}

The main pathway of $5 \mathrm{HT}$ metabolism (Udenfriend, 1958) is shown in the Figure.

Pyridoxal-5-phosphate is a coenzyme of 5hydroxytryptophan decarboxylase (5HTPD) involved in the formation of $5 \mathrm{HT}$; it may be supplied to the body in any of the forms of vitamin B6, pyridoxine, pyridoxal, or pyridoxamine (McCormick, Gregory, and Snell, 1961).

Dahler (1963) has demonstrated that infants may have a relative deficiency of vitamin B6. After a tryptophan load test, 4 of 25 full-term and 9 of 19 premature infants responded with an increased xanthurenic acid output. Berman et al. (1965) have shown that low values of 5HT in newborn infants may be caused by relative deficiencies of both 5HTPD and vitamin B6. Thus, the inability to raise cord blood 5HT values in the present work, in spite of maternal vitamin B6 supplementation, is assumed to be due either to a remaining relative deficiency of pyridoxine or to a low level of apoenzyme 5HTPD in the newborn infant.

It is unlikely that any degree of pyridoxine deficiency would have persisted after a supplementation of 10-50 mg. per day. Zartman, Barnes, and Hicks (1955) and Wachstein, Kellner, and Ortiz (1960) have demonstrated that such deficiency in pregnant women can readily be corrected by the administration of 2-25 mg. B6 per day.

Pyridoxine presumably crosses the placenta in amounts sufficient for the infant's needs; in fact, levels are normally higher in the cord than in maternal blood (Wachstein et al., 1960; Karlin and Dumont, 1963) and can be further increased by maternal pyridoxine supplementation (Coursin and Brown, 1961). In addition, the fall usually observed in infant blood levels during the first 24 hours of life does not occur in the infants of mothers who have received supplementary vitamin B6 (Coursin and Brown, 1961).

Many enzyme systems are immature during the foetal and newborn periods of life (Driscoll and Hsia, 1958). Among these, 5HTPD activity has been found to be low or absent in newborn and foetal rat kidneys (Huang, Tannenbaum, and Hsia, 1960; Smith, Stacey, and Young, 1962; Berman et al., 1965) and in rat brain (Nachmias, 1960). It is thus possible that the inability of vitamin B6 to raise cord levels of $5 \mathrm{HT}$ is due to a marked though physiological deficiency of 5HTPD.

A possible alternative explanation stems from the finding that a variety of hormones can interfere with pyridoxine-dependent enzymes (Yamada, Yazaki, Sawaki, and Utumi, 1958; Jolles-Bergeret, LaBouesse, and Chatagner, 1960; Scardi, Iaccarino, and Scarano, 1962). In particular, Mason and Schirch (1961) have shown that oestrogens will inhibit 5HTPD in vitro. Should such inhibition occur in vivo, it may be that high circulating maternal oestrogen levels antagonize any ability pyridoxine possesses to prime the 5HTPD system.

A rise in maternal $5 \mathrm{HT}$ was noted in groups $\mathrm{B}$ and $\mathrm{C}$ at parturition, but not in group $\mathrm{A}$. During the post-partum period both control and supplemented groups showed a significant rise; similar results have been obtained by S. F. Contractor and M. Sandler (personal communication, 1965). Virtually all circulating $5 \mathrm{HT}$ is contained in blood platelets

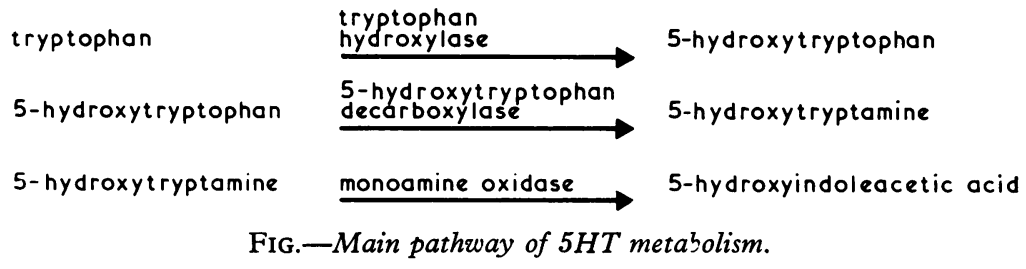


(Stacey, 1958), but since platelet counts did not change significantly during the period of the investigation, an explanation must be sought elsewhere.

Vitamin B6 deficiency causes a decrease of available pyridoxal-5-phosphate and a depression of 5HTPD activity which is corrected by its administration (Buzard and Nytch, 1957; Pogrund, Drell, and Clark, 1961). This may explain why the supplemented groups were able to increase their 5HT levels at parturition. A further availability of dietary vitamin $\mathrm{B} 6$ to the mother would occur during the post-partum period when the foetus made no further demands. It would be interesting, however, if an alternative explanation were eventually to be found in terms of release of 5HTPD from inhibition by circulating oestrogens.

\section{Summary}

Neither cord blood 5-hydroxytryptamine level nor urinary 5-hydroxyindoleacetic acid output in the newborn infant can be increased by maternal ingestion of pyridoxine during the last 3 to 5 weeks of pregnancy. Previous work had shown an increase after direct administration of the vitamin to the newborn infant.

Increased maternal blood levels of 5HT were found in both test and control groups during the post-partum period, but only in test groups at parturition. The possible implications of these results are discussed in terms of relative pyridoxine deficiency and 5-hydroxytryptophan decarboxylase maturity.

This study was supported in part by grant No. TIAm-2186-05 from the U.S. Public Health Service, to whom I wish to express my thanks. I am also grateful to Professor S. G. Clayton for allowing me access to his patients, to Dr. Richard Beard for his help in the arrangements for collection of blood, to Drs. Merton Sandler and Soli Contractor for helpful advice, and to the National Society for Mentally Handicapped Children for purchase of equipment.

\section{REFERENCES}

Berman, J. L., Justice, P., and Hsia, D. Y.-Y. (1965). The metabolism of 5-hydroxytryptamine (serotonin) in the newborn. $\mathcal{F}$. Pediat., 67, 603.
Buzard, S. A., and Nytch, P. D. (1957). The relation of dietary pyridoxine to the 5-hydroxytryptophan decarboxylase activity of rat kidney. F. biol. Chem., 229, 409.

Contractor, S. F. (1964). The estimation of 5-hydroxytryptamine in human blood. Biochem. Pharmacol., 13, 1351.

Coursin, D. B., and Brown, V. C. (1961). Changes in vitamin B during pregnancy. Amer. F. Obstet. Gynec., 82, 1307.

Dahler, R. P. (1963). Untersuchungen über den Tryptophanabbau und den Vitamin $\mathbf{B}_{6}$-Stoffwechsel beim Neugeborenen und beim Säugling. Ann. paediat. (Basel), 200, 346.

Driscoll, S. G., and Hsia, D. Y.-Y. (1958). The development of enzyme systems during early infancy. Pediatrics, 22, 785.

Hazra, M., Benson, S., and Sandler, M. (1965). Blood 5-hydroxytryptamine levels in the newborn. Arch. Dis. Childh., 40, 513.

Huang, I., Tannenbaum, S., and Hsia, D. Y.-Y. (1960). Development of 5-hydroxytryptophan decarboxylase activity in rat kidney. Nature (Lond.), 186, 717.

Jolles-Bergeret, B., LaBouesse, J., and Chatagner, F. (1960). Influence des hormones thyroidiennes sur la désulfuration de la cystéine par foie due rat. Comparaison du comportement de la désulfuration avec celui d'autres réactions enzymatiques necessitant le phosphate de pyridoxal. Bull. Soc. Chim. biol. (Paris), 42, 51.

Karlin, R., and Dumont, M. (1963). Contribution à l'étude du taux de vitamine $\mathbf{B}_{6}$ pendant l'accouchement dans le sang total de la mère et dans le sang total du cordon. Gynéc. et Obstét., 62, 281.

Mason, M., and Schirch, L. (1961). Inhibition of $\mathrm{B}_{6}$-enzymes by free and conjugated estrogens. Fed. Proc., 20, 200.

McCormick, D. B., Gregory, M. E., and Snell, E. E. (1961). Pyridoxal phosphokinases. I. Assay, distribution, purification, and properties. F. biol. Chem., 236, 2076.

Mitchell, R. G., and Cass, R. (1959). Histamine and 5-hydroxytryptamine in the blood of infants and children. $\mathcal{F}$. clin. Invest., 38, 595.

Nachmias, V. T. (1960). Amine oxidase and 5-hydroxytryptamine in developing rat brain. $\mathcal{F}$. Neurochem., 6, 99.

Pogrund, R. S., Drell, W., and Clark, W. C. (1961). Metabolism of 3-hydroxy- and 3, 4-dihydroxyphenylpyruvic acid in vivo. F. Pharmacol., 131, 294.

Scardi, V., Iaccarino, M., and Scarano, E. (1962). The action of sulphate and phosphate esters of oestrogens on the reconstitution of two pyridoxal 5-phosphate-dependent enzymes. Biochem. $\mathcal{F} ., 83,413$.

Smith, S. E., Stacey, R. S., and Young, I. M. (1962). 5-Hydroxytryptamine and 5-hydroxytryptophan decarboxylase activity in the developing nervous system of rats and guinea-pigs. In Pharmacological Analysis of Central Nervous Action (Proc. First Int. Pharmacol. Meeting, Vol. 8, ed. W. D. M. Paton and P. Lindgren), p. 101. Pergamon Press, Oxford.

Stacey, R. S. (1958). Platelets and 5-hydroxytryptamine. In 5-Hydroxytryptamine, ed. G. P. Lewis, p. 116. Pergamon Press, London.

Udenfriend, S. (1958). Metabolism of 5-hydroxytryptamine. In 5-Hydroxytryptamine, ed. G. P. Lewis, p. 43. Pergamon Press, London.

- Titus, E., and Weissbach, H. (1955). The identification of 5-hydroxy-3-indoleacetic acid in normal urine and a method for its assay. F. biol. Chem., 216, 499.

Wachstein, M., Kellner, J. D., and Ortiz, J. M. (1960). Pyridoxal phosphate in plasma and leukocytes of normal and pregnant subjects following $\mathbf{B}_{6}$ load tests. Proc. Soc. exp. Biol. (N.Y.), 103,350 .

Yamada, K., Yazaki, C., Sawaki, S., and Utumi, S. (1958). Inhibitory effect of growth hormone on some vitamin $\mathbf{B}_{6}$ enzyme systems of Escherichia coli. F. Vitaminol., 4, 274.

Zartman, E. R., Barnes, A. C., and Hicks, D. J. (1955). Observations on pyridoxine metabolism in pregnancy. Amer. $\mathcal{F}$. Obstet. Gynec., 70, 645. 